九州大学学術情報リポジトリ

Kyushu University Institutional Repository

\title{
Socio-economic Impact of COVID-19 till Second Wave in India: A case study
}

\section{Saren, Sagar}

Department of Energy and Environmental Engineering, Interdisciplinary Graduate School of Engineering Sciences, Kyushu University

Thu, Kyaw

Department of Energy and Environmental Engineering, Interdisciplinary Graduate School of Engineering Sciences, Kyushu University

Miyazaki, Takahiko

Department of Energy and Environmental Engineering, Interdisciplinary Graduate School of Engineering Sciences, Kyushu University

https://doi.org/10.5109/4738590

出版情報: Proceedings of International Exchange and Innovation Conference on Engineering \& Sciences (IEICES). 7, pp. 210-217，2021-10-21. 九州大学大学院総合理工学府 バージョン:

権利関係 : 


\title{
Socio-economic Impact of COVID-19 till Second Wave in India: A case study
}

\author{
Sagar Saren $^{1 *}$, Kyaw Thu ${ }^{1,2}$, Takahiko Miyazaki ${ }^{1,2}$ \\ ${ }^{1}$ Department of Energy and Environmental Engineering, Interdisciplinary Graduate School of Engineering Sciences, \\ Kyushu University, 6-1 Kasuga-koen, Kasuga-shi, Fukuoka 816-8580, Japan, \\ ${ }^{2}$ Research Center for Next Generation Refrigerant Properties (NEXT-RP) \\ International Institute of Carbon-Neutral Energy Research (I2CNER), Kyushu University \\ 744 Motooka, Nishi-ku, Fukuoka 819-0395, Japan. \\ *Corresponding author email: saren.sagar.203@s.kyushu-u.ac.jp
}

\begin{abstract}
COVID-19 pandemic shrouded the humanity in the dark clouds of deaths, long term health issues, economic deterioration, and social crisis. Economically developed and developing countries alike faced the wrath of the pandemic severely. India being the $2^{\text {nd }}$ most populated country in the world, having a middle income developing market with sixth largest economy, was no exception. After the US, India secured its position of having the second highest number of cases and deaths across the world, throughout its two phases of pandemic spread. Lack of obedience towards the COVID-19 guidelines of social distancing and fueled by the overburdened and crippled health infrastructure led to the devastation of the second wave. People from different financial classes were affected inequitably, particularly underprivileged ones suffering from reverse-migration, unemployment and psychological distress. An analysis of the development of the pandemic, the contributing factors and the socio-economic impacts have been carried out.
\end{abstract}

Keywords: COVID-19; India; Second wave; Vaccination; Socio-economic impact

\section{INTRODUCTION}

Coronaviruses, belonging to the family Coronaviridae, are single stranded, positive-sense RNA viruses [1]. Historically three major outbreaks of the Coronaviruses have been recorded: (i) "Severe Acute Respiratory Syndrome" (SARS) in China, 2003 [2], (ii) "Middle-east Respiratory Syndrome" (MERS) in Saudi-Arabia in 2012 [3] and (iii) MERS in South Korea in 2015 [4]. The recent or fourth outbreak in December, 2019 has been identified in Wuhan, the capital city of Hubei province in China [5]. With the symptoms of viral pneumonia, the outbreak has been determined to be transmitted via a biological pathogen named novel coronavirus and subsequently the World Health Organization (WHO) declared the official name of the disease and the causing virus as coronavirus disease 2019 (COVID-19) and severe acute respiratory syndrome coronavirus 2 (SARS-CoV-2) respectively [6]. Starting from Wuhan, the coronavirus rapidly spread throughout the country as well as outside China. On $13^{\text {th }}$ January, 2020, the first case of coronavirus in Thailand was officially reported as the first outbreak outside of China [7]. On $21^{\text {st }}$ January, 2020, the first confirmed case of COVID-19 was reported in USA who came back from Wuhan on January 15 [7]. On January $23^{\text {rd }} 2020$, Wuhan was cut off from the rest of the world via all modes of transportation and was kept in a strict lockdown [8]. On $30^{\text {th }}$ January 2020, WHO declared this spread as a "public health emergency of international concern" and later gave the official name of the virus as mentioned before. Gradually different countries were witnessing major surge in cases and deaths including France, Italy, Iran, USA, Russia, India etc. [9].

The severity of the COVID-19 was apparent from the alarming number of confirmed cases and deaths along with its rapid rate of infection in some of the nations. As of $9^{\text {th }}$ May, 2020, the number of cases and deaths reported soared at 83,976 and 4,639 respectively in China [10]. The European countries were relatively much more affected by the COVID-19 pandemic which is evident from the numbers. By April $24^{\text {th }}, 2020$ in Italy, 192,994 number of cases and 25,969 number of deaths had been reported [11]. Italy was followed by France, United Kingdom and Germany in terms of total number of cases.
But around this time, USA was witnessing the highest number of daily confirmed cases, crossing the mark of a million cumulative confirmed cases by the end of April 2020. In terms of cumulative confirmed cases, by the end of the year 2020, USA, India and Brazil were holding the top positions with 20.10 million, 10.27 million and 7.68 million cases respectively. The same trend has been shown in figure 1 [12]. Different countries experienced multiple waves of COVID-19 cases at different times for different sustenance period, as it is evident from the figure 2 [12]. It can be seen that USA had observed several waves, particularly during the period of November, 2020 to January, 2021, in terms of daily number of cases with 7-day rolling average. India experienced two waves till June, 2021, the second wave being much more intensive and deadlier than the first one occurred during September, 2020.

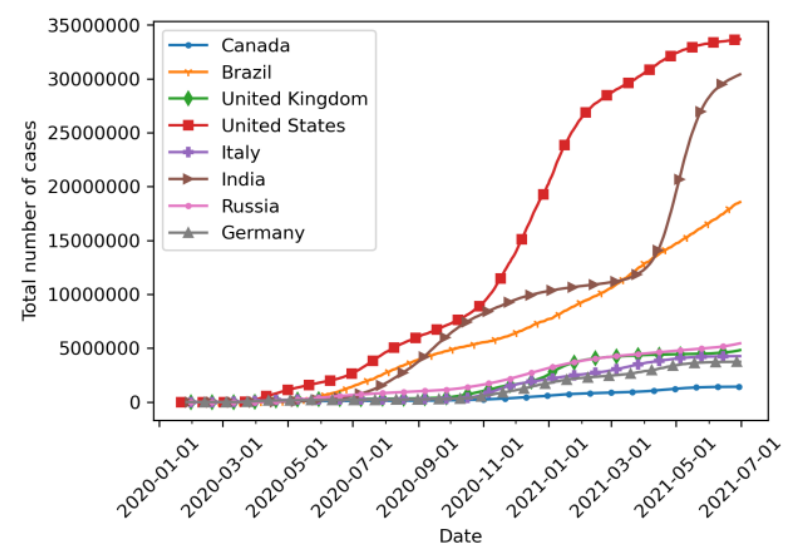

Figure 1: Total number of COVID-19 cases 


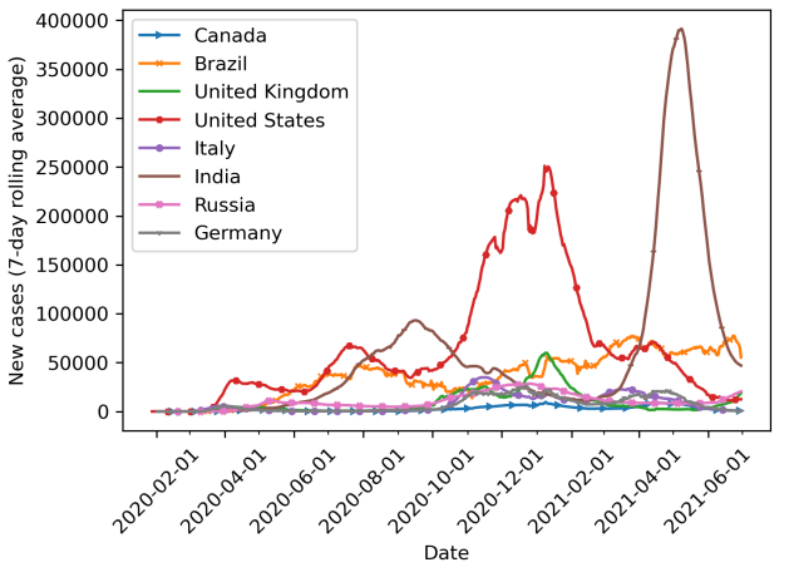

Figure 2: Daily rate of COVID-19 confirmed cases

The occurrence of multiple spikes in the COVID-19 cases have been attributed to the negligence in the precautionary measures for avoiding spread of corona virus e.g. hand-washing, mask wearing and social distancing; along with reopening of multiple social gathering places including malls, theatres, restaurants etc. causing further transmission of the coronavirus [13]. Centers for Disease Control and Prevention (CDC) have explained the different variants of concern of the SARSCoV-2 which are much more transmissible and more resistant to treatments or vaccines [14]. These new variants are also contributory to the increase in the number of COVID-19 cases across the world, especially in US and India.

The preventive measures taken to reduce the spread of coronavirus worldwide significantly affected public health situation, peoples' livelihoods, and the economic growth of the nations. On the other hand, a positive impact on the energy and environment has been observed due to the reduction of pollution by the industrial and transportation sector. COVID-19 pandemic brought about the largest decline in the global $\mathrm{CO} 2$ emissions as well as acceleration in the power sector decarbonisation [15]. India being one of the worst affected countries in the world, in this study, the development timeline and the socio-economic impacts of the COVID-19 pandemic have been discussed in the context of Indian case.

\section{COVID-19 TIMELINE IN INDIA}

India has been one of the worst affected countries by the COVID-19 pandemic. As of July 2021, the COVID-19 pandemic pattern in India can be classified in two phases, namely first phase from March 2020 to December 2020 and second phase during March, 2021 to June 2021. There is a substantial difference between the morbidity, mortality, and relevant factors contributing to the pandemic between the two phases. The following subsections discuss the details of both the phases of the pandemic as well as the vaccination effort undertaken.

\subsection{First Wave}

In Kerala, the first 3 victims of the COVID-19 cases were reported between $30^{\text {th }}$ January 2020 and $3^{\text {rd }}$ February 2020, who had returned from Wuhan, China. More than 3400 people, suspected to have come in contact with those patients, were put in quarantine to contain the outbreak. The subsequent 2 patients had a travel history to Italy and Dubai. Till $15^{\text {th }}$ March 2020, the number of cases were limited to 107 . By $30^{\text {th }}$ March 2020, the statistics stood at 1071 cases. On $16^{\text {th }}$ March, 2020, Ministry of Health, Family Welfare (MoHFW) issued an advisory for social distancing to restrict the spread of COVID-19. On 19 $9^{\text {th }}$ March, 2020, Prime Minister of India, Narendra Modi, appealed to the nation to observe "People's curfew" on $22^{\text {nd }}$ March, 2020. Later, on $24^{\text {th }}$ March, 2020, PM Modi announced a strict 21 days' lockdown to curb the spread of the coronavirus. This lockdown was later extended till $31^{\text {st }}$ May, 2020 for further effectiveness in battling the pandemic. Meanwhile, due to religious congregation held even during the lockdown period, a sudden increase in the number of cases was observed. This caused the place "Nizamuddin" in Delhi (capital of India) to become a major hotspot of COVID-19 in India and by $18^{\text {th }}$ May, 2020 the number of cases already crossed 100,000. But compared to the other countries at the same time, the number of cases was much inferior in India due to the draconic lockdown and its successful implementation. After lifting the lockdown, around the middle of September, 2020, the highest number of cases was recorded at that time, establishing the peak of the $1^{\text {st }}$ wave of the COVID-19 pandemic in India. On Sept. 11, 2020, the number of cases was recorded to be 97570 [12]. In terms of mortality also, India was faring well compared to the other hotspots across the world, despite being the one of the most densely populated countries. On $15^{\text {th }}$ September, 2020, India had a mortality rate of 0.85 per million people, whereas on the same day, it was 2.59 per million populations in the US [12]. Figure 3 depicts the mortality and morbidity rates of COVID-19 in India [12].

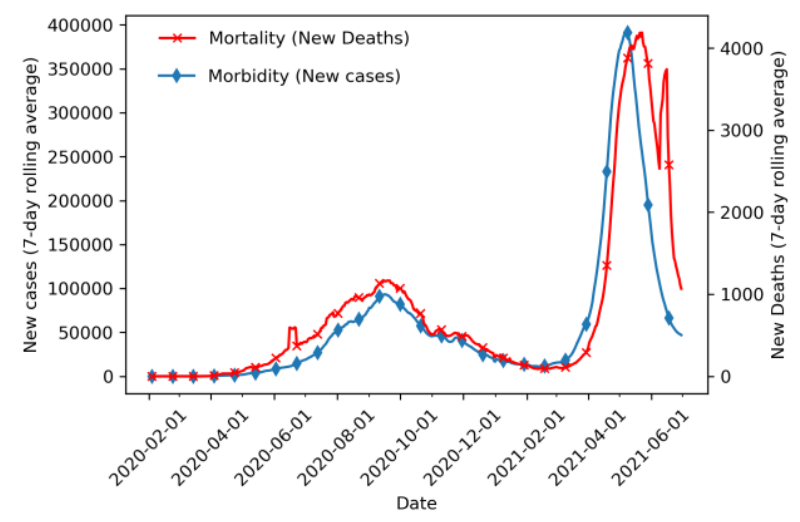

Figure 3: Mortality (new deaths) and Morbidity (new cases) rate of COVID-19 in India

Apart from implementation of lockdown across the nation, as a precautionary and defensive measure against the pandemic, COVID-19 tests were being rapidly carried out to detect the coronavirus as soon as possible and accordingly arrange for quarantine measurements to contain the spread. During August, 2020 to November, 2020, more than a million tests per day were being carried out [12]. Different kinds of testing facilities including Point-of-Care molecular diagnostic assays, Real-time PCR test, rapid antibody test and point-of-care rapid antigen detection test for early detection of COVID-19 were being carried out [16]-[18]. In January 2020, starting from a single laboratory testing for COVID-19, at the Indian Council of Medical Research's National Institute of Virology, Pune, by $20^{\text {th }}$ May 2020, 
555 laboratories were set up across the country to deal with COVID-19 cases [19]. In October, 2020, the "Indian Supermodel", a mathematical simulation model initiated by the Department of Science and Technology, govt. of India, predicted that by February, 2021 the pandemic would come under control based on the assumption of herd immunity [20].

\subsection{Second Wave}

Till March 2021, after the first wave, India witnessed a very low rate of infection, it was assumed that the pandemic was under control and herd immunity was achieved. In early March, 2021, Dr. Harsh Vardhan, Indian minister of health, declared that India was in the "endgame" of the epidemic [21]. Since the beginning of April, 2021, a rapid surge in the number of COVID-19 cases were observed in India. As of May 4, 2021, more than 20.2 million cases were reported, with a 7-day rolling average of 381,123 cases per day. On May $6^{\text {th }}$, 2021 , India reached the peak of the second wave with a whopping 414,188 cases, which is more than 4 times than the peak number of cases recorded in the first wave in September, 2020. Even though the fatality was not as severe as the other countries in terms of relative to the total population, India certainly spectated a huge number of deaths, which was not only unprecedented, but also India was unprepared for. India had a rolling average of more than 4,000 fatalities per day, with a peak of 7,374 number of deaths on $10^{\text {th }}$ June, 2021. From figure 3 it is evident that although the duration of the second wave was shorter than the first wave, the intensity of the second wave in terms of both morbidity and mortality was far more severe. India reached the $2^{\text {nd }}$ position just underneath the US in terms of total number of cases by the end of the second wave with total morbidities count at 30.55 million and fatalities number at 402,005.

Several reasons can be ascribed for the sudden spout of the number of cases in the second wave. Due to the economic downfall caused by the lockdown during the first wave, the desire to reopen society and rebuild the economic growth spurred the belief that there wouldn't be a second wave. Full opening of society with unrestrained crowding, mass gatherings, large scale travel and lack of personal protective measures were pretty much responsible for the spike in the number of cases [22]. One of such examples is the super-spreader event of "Kumbh Mela", a festival where millions of devotees gather and take bath in the river of Ganges, which increased the number of COVID-19 cases in the state of Uttarakhand by $1800 \%$ [23]. Also, holding huge election rallies without paying heed to any kind of safety measurements including social distancing and mask wearing during the advent of the second wave certainly contributed to the pandemic growth in the country [24]. The emergence and dominance by the new variants of the coronavirus including B.1.617, classified as "variants of concern" by WHO might be one of the contributing factors to the sharp spike in the COVID-19 cases in India [25]. In spite of being stuck in the unsteerable circumstance in the midst of the grave COVID-19 second wave, incidences such as the mass gathering of around ten thousand individuals at the funeral procession of an Islamic leader in the state of Uttar Pradesh on May 10, 2021 added fuel to the fire [26]. The crisis was further aggravated by the collapse of the healthcare system via lack of oxygen supply in the hospitals and shortage of beds in the hospitals [27]. The lack of coordination between the central and the state governments also turned out to be a major contributory factor for the second wave, which included constitutional restriction of health being a state subject, limitation of the state government in terms of availability of resources, and restriction of the premier medical institutions by being confined to only an advisory for public health of the state [28].

Apart from the intensity difference both in morbidities and mortalities between first and second wave, there were further contrasts observed between these waves. The second wave witnessed a younger demography (the mean age of the patients was altogether lower with a higher proportion of patients within the more youthful age bunch interims of less than 20 years, and 20-39 years), lesser comorbidities, breathlessness in greater frequency and higher mortalities than the first wave [29]. Also, the oxygen supply requirement and mechanical ventilation requirement were significantly higher and disease spread was much faster in the second wave than the first wave, even though the availability and supply of PPE kits and bed capacity was enhanced during the same period [30].

\subsection{Vaccination Drive}

On $16^{\text {th }}$ January 2021, after multiple phases of trials conducted, India started its largest and fastest ever vaccination drive across the nation with the aim of vaccinating 300 million people by the end of August, 2021 , with priority given to health workers, frontline workers, elderly people and people with comorbidities. Mainly two kinds of vaccines were being administered to the people, Covishield (by Serum Institute of India) and Covaxin (by Bharat Biotech Information System) [31]. Being the world's leading pharmaceutical products manufacturers and exporters ("pharmacy of the world"), and with the previous experience of carrying out large and targeted vaccination campaigns against deadly diseases such as measles, tetanus, and diphtheria, India took on the daunting task of the mass immunization of the people against the fatal coronavirus. Government's press information bureau on Feb 8, 2021, declared that within just 24 days, India was able to achieve the exceptional feat of vaccination of 6 million people. Starting from May, 2021, the vaccine eligibility was expanded to include all people aged 18 or older. As of $6^{\text {th }}$ July 2021, a cumulative of 291,172,390 number of people were administered the $1^{\text {st }}$ dose of vaccine and $66,381,222$ number of individuals were given the $2^{\text {nd }}$ dose of COVID-19 jab. But these numbers are significantly low when compared with the records of vaccinations in other countries with respect to the population of the respective nations. A depiction of the cumulative amount of vaccination given per 100 people has been provided in figure 4 [12]. 


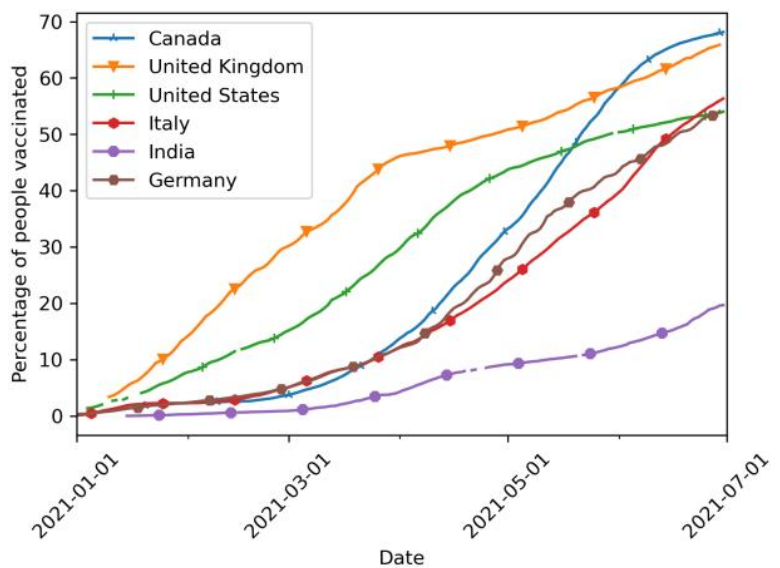

Figure 4: Percentage of people receiving at least one dose of COVID-19 vaccination

The significant drawback in the vaccination drive of India has been attributed to multiple factors. The gigantic difference between the demand and supply of the vaccines, especially in a country, having the $2^{\text {nd }}$ largest population in the world, has been attributed as an obvious reason for the crisis of vaccine occurred during May 2021, after the drive was expanded to include all eligible adults [32]. According to another report, the cause for inadequate supply of the COVID-19 vaccine has been attributed to the delay in ordering of the vaccines by the government (waited till January, 2021) as well as the "Vaccine Diplomacy" adopted by the government of India, by the virtue of which India exported more amount of jabs than administered to the people of India by March, 2021 [33]. According to Government Data, India shipped more than 66 million doses overseas since January, 2021, which was enough to vaccinate the whole of Delhi, Mumbai and Kolkata (metropolitan cities in India). Even during the second wave, India made shipment to Paraguay on April 22, 2021, when India broke the world record in terms of the new infections [34].

\section{SOCIO-ECONOMIC IMPACT OF COVID-19 IN INDIA}

COVID-19 pandemic had an immense impact on the socio-economic functioning in India during its sustenance across the two phases. The influence has been both immediate and long-term in nature from the social and economic perspectives, which are also correlated with each other.

\subsection{Social Impact}

As the COVID-19 severely crippled the health/medical infrastructure, its direct influence was on the infected patients and their relatives. Particularly during the second phase of COVID-19, due to the sharp rise in the number of cases, there was a dearth of medical supplies including lifesaving oxygen, beds in the hospitals as well as antiviral drug Remdesivir in pharmacies, which caused an occurrence of turmoil across the country. People were rushing from one hospital to another in search for medical supplies. As hospitals were overflowing, they were turning away new patients. Streets were filled with crowd of seriously ill patients and their loved ones desperately trying to arrange stretchers and oxygen supplies [35]. Even social media crowdsourcing was being carried out to gather the required supply [36]. The unexpected amount of deaths overwhelmed the funeral centers, thus there had been a shortage of people as well as supplies such as woods, for conducting the funerals (cremation). The second wave of COVID-19 soon became the unprecedented cultural cataclysm, forcing the Indian culture to challenge the way it handles its dead [37].

During the first phase, as the intensity of the cases were relatively lesser compared to the second wave, the crisis for medical supplies was not much significant. But, the pandemic affected the population indirectly via its novelty (unknown nature of the coronavirus) and the measures taken to prevent it. The frontline workers namely doctors, nurses, health professionals, police were shunned from the society (particularly in the residential areas) due to the fear of being infected. The treatment they faced were general ostracism and the threat of being evicted [38]. During the initial period of the pandemic, people with travel history were being asked to isolate themselves in the residential complexes, but due to major misunderstanding, their reactions were aggressive towards the neighbors. Also, the fear of being thrust out of homes and societies, led these people to nondisclosure of their travel history, which in turn led to the risk of further spread of the coronavirus [39]. On the other hand, due to the strict imposition of the lockdown with very little time to get prepared, people resorted to panic purchasing and stocking of grocery and essential items, which not only heightened the risk of infection, but also caused a rapid scarcity of the supplies for the relatively underprivileged people [40]. This exposed the clannish nature of people at a time of crisis.

Due to the presence of socio-economic disparity, the effect of the pandemic varied greatly between the different sections of the society. The privileged section with sufficient financial strength had a greater adaptive capacity for resource management during lockdown. But they still faced challenges in availing medical services particularly during the second phase. The middle class people suffered from psychological stress caused by the risk of infection worries, shortages of medical supplies, financial burden of medical treatments and loss of livelihoods [41]. The ones who faced the most severe impact of the pandemic were the lower middle class and poor people in India. Especially the migrant workers and homeless people were the most vulnerable people in this pandemic. The migrant laborers include the underprivileged people and laborers who went to major cities for employment opportunities and a chance of earning livelihoods from their rural home states. But due to the sudden imposition of the lockdown on $24^{\text {th }}$ March, 2020, due to the limited employment opportunities, impending fear of unknown future and financial crisis, around 50,000-60,000 individuals migrated from urban to rural areas of origin in an interim of only few days. This was the second largest mass migration in its history after the Partition of India in 1947 [42]. Due to unavailability of public transports because of lockdown, the workers were forced to walk with very limited resources for hundreds of miles with children, pregnant women, old people [43]. Proneness for new viral infections, high predominance of physical health indispositions, hostile psychosocial issues like absence of family support and caretaker during the crisis, their limitations to follow the rules and regulations of personal 
safety during the COVID-19 crisis, social marginalization, and inability to timely access the psychiatric services made this community particularly vulnerable to the harrowing psychological distress [44]. Apart from the urban underprivileged workers, the poverty prevalent in India's rural and semi-rural areas, became an important factor towards the increased percentage of the confirmed cases in the countryside in the second phase, with an estimation of $65 \%$ of new cases through the beginning of June, 2021 belonging to those areas, despite sparse COVID-19 testing outside the cities. Lack of access to essential healthcare, misdiagnosis of the health problems, pandemic denial among the poor people and social stigma intensified the spread of the virus. Even there had been evidences of people dumping bodies in the river Ganges due to lack of crematorium space and materials [45].

COVID-19 pandemic produced a digital divide among the people in availing the necessary services. For vaccination rollout among the individuals between 18 to 45 years' age, CoWIN mobile application was developed and launched in May, 2021. One had to register and make a reservation in the app for the vaccination. But the inaccessibility of internet in many corners of the nation led to disparity in availing vaccination [46]. According to a 2018 report by Ministry of Statistics and Programme Implementation, govt. of India, only $20 \%$ of the population can access the internet due to geographical and economic adversity [47]. There were instances where a person had to travel more than 20 kilometers for an internet kiosk to book a vaccination appointment [48]. Apart from the vaccination, as the schools and colleges were shut down to prevent the spread of the virus, all the classes were being held online. This included holding live online lecture, examination etc. Here also only the privileged few could afford the necessary internet connection for availing the online education. Lack of smartphones (only $42 \%$ of the mobile phones are smartphones in India [49]), data costs, technology illiteracy and unavailability of mobile connections led to closure of means of escaping poverty for the underprivileged communities [50].

\subsection{Economic Impact}

As an expected consequence to the heavy-handed measures of nationwide lockdown, India witnessed a drastic economic downfall which led to loss of livelihoods, exacerbation of existing inequalities and worsening food insecurity. The GDP growth rate in the $1^{\text {st }}$ and $2^{\text {nd }}$ quarter of financial year 2021 , had been in negative numbers, with values $-24.4 \%$ and $-7.4 \%$ respectively, compared to the previous financial year at constant rate (2011-12). This sharp decline in the economic performance was caused by the strict lockdown imposition, which led to halting of supply chain, manufacturing, retail industries etc. In terms of Gross Value Added (GVA), construction, manufacturing and trade industry faced the greatest loss of $49.47 \%$, $35.9 \%, 48.05 \%$ in Q1 of FY2021 respectively, compared to FY2021 at constant rate (2011-12) [51]. Figure 5 depicts the trend in the GVA growth rate for four quarters in FY2021. Economic improvement was seen towards $4^{\text {th }}$ quarter, as after the lockdown was over, the economic activities started to function again. The agricultural, forestry and fishing sectors were almost unaffected, if not improved, due to the lesser impact of pandemic in these rural economic sectors.

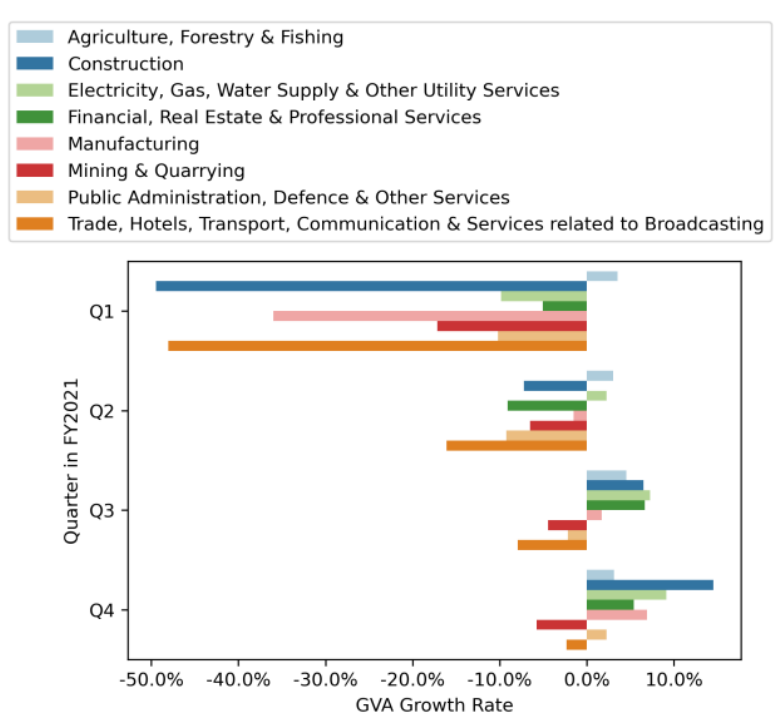

Figure 5: GVA Growth Rate in FY2021 for various sectors

Due to this economic improvement in various sectors, India witnessed $0.5 \%$ and $1.6 \%$ marginal growth in GDP in $3^{\text {rd }}$ and $4^{\text {th }}$ quarter of FY2021, but overall GDP growth was the lowest till now with a decline of $7.3 \%$. The apparent perception of getting the situation under control was marred by the advent of the second wave of COVID19. This time the impact on the rural areas were much more severe, affecting the agricultural sector unlike the first wave. The effect on the manufacturing and service sectors is also expected to be more severe than the first wave. On the other hand, the expectation of economic revival is present because of the relatively shorter span of the second wave [52].

The macroeconomic statistics don't properly justify the underlying large and unequal problems in the households and workers in the country [53]. The already existing economic inequality has been heightened due to COVID19 pandemic. After the first wave of pandemic, the poor population in India is anticipated to be increased by more than double as well as a one third decline in the middle class population has been estimated [54]. Not only people had lost months' worth of income (as high as 3 months [55]) due to the lockdown during the first wave, but also urban unemployment rate jumped from $8.8 \%$ in April June 2019 to $20.8 \%$ in April - June, 2020 [56]. The long term effect of the second wave from both the perspectives of macroeconomic statistics and poor/middle class peoples' livelihood is yet to be seen.

\section{CONCLUSIONS}

From the discussion it is apparent that the government's complacency of winning the fight against COVID-19 and lack of proper planning led to the devastating crisis of second wave as well as in the shortage of COVID-19 jabs, giving rise to a halt in the nationwide vaccination drive. Needless to say, lenience against following the safety protocols for COVID-19 by the common people was equally responsible towards the development of the fatal crisis, which turned out to be adversely affecting towards the social and economic aspects predominately. The contribution of the damage caused by the first wave also 
was apparent in the consequences due to the second wave. From socio-economic perspective, the people of India not only lost their near and dear ones, but also the burden of the intensity was experienced by people from all sections - from frontline workers to daily wage earner. Not only people went through psychological trauma, but also due to the economic losses incurred, the poorest and lower-middle class section people lost their livelihood, expanding the region of poverty across the nation. COVID-19 being probably a once in a century event, the government and the general people need to be adaptive to this new crisis by following safety protocols, being vaccinated and being a little more compassionate towards the underprivileged ones.

\section{REFERENCES}

[1] Y. Chen, Q. Liu, and D. Guo, "Emerging coronaviruses: Genome structure, replication, and pathogenesis," Journal of Medical Virology, vol. 92, no. 4. John Wiley and Sons Inc., pp. 418423, 01-Apr-2020.

[2] Y. Huang, "THE SARS EPIDEMIC AND ITS AFTERMATH IN CHINA: A POLITICAL PERSPECTIVE," 2004.

[3] M. E. Killerby, H. M. Biggs, C. M. Midgley, S. I. Gerber, and J. T. Watson, "Middle east respiratory syndrome coronavirus transmission," Emerg. Infect. Dis., vol. 26, no. 2, pp. 191-198, 2020.

[4] M. Willman, D. Kobasa, and J. Kindrachuk, “A Comparative Analysis of Factors Influencing Two Outbreaks of Middle Eastern Respiratory Syndrome (MERS) in Saudi Arabia and South Korea," mdpi.com, 2019.

[5] J. Cohen and D. Normile, "New SARS-like virus in China triggers alarm," Science, vol. 367, no. 6475. American Association for the Advancement of Science, pp. 234-235, 17-Jan2020.

[6] "Naming the coronavirus disease (COVID-19) and the virus that causes it," 2020. [Online]. Available:

https://www.who.int/emergencies/diseases/nove 1-coronavirus-2019/technical-guidance/namingthe-coronavirus-disease-(covid-2019)-and-thevirus-that-causes-it. [Accessed: 29-Jun-2021].

[7] "A Timeline of COVID-19 Developments in 2020," 2021. [Online]. Available: https://www.ajmc.com/view/a-timeline-ofcovid19-developments-in-2020. [Accessed: 29Jun-2021].

[8] "Wuhan, Center of Coronavirus Outbreak, Is Being Cut Off by Chinese Authorities - The New York Times," 2020. [Online]. Available: https://www.nytimes.com/2020/01/22/world/asi a/china-coronavirus-travel.html. [Accessed: 29Jun-2021].

[9] "W.H.O. Declares Global Emergency as Wuhan Coronavirus Spreads - The New York Times," 2020. [Online]. Available: https://www.nytimes.com/2020/01/30/health/cor onavirus-world-health-organization.html.

[Accessed: 29-Jun-2021].

[10] Y. F. Lin et al., "Spread and impact of COVID-
19 in China: A systematic review and synthesis of predictions from transmission-dynamic models," Frontiers in Medicine, vol. 7. Frontiers Media S.A., pp. 1-11, 18-Jun-2020.

[11] “COVID-19 Map - Johns Hopkins Coronavirus Resource Center." [Online]. Available: https://coronavirus.jhu.edu/map.html. [Accessed 01-Jul-2021].

[12] "COVID-19 Data Explorer - Our World in Data." [Online]. Available: https://ourworldindata.org/coronavirus.

[Accessed: 01-Jul-2021].

[13] "Coronavirus Second Wave? Why Cases Increase | Johns Hopkins Medicine," 2020. [Online]. Available: https://www.hopkinsmedicine.org/health/conditi ons-and-diseases/coronavirus/first-and-secondwaves-of-coronavirus. [Accessed: 29-Jun-2021].

[14] "About Variants of the Virus that Causes COVID-19 | CDC," 2021. [Online]. Available: https://www.cdc.gov/coronavirus/2019-

ncov/variants/variant.html. [Accessed: 29-Jun2021].

[15] "Global Energy Review: CO2 Emissions in 2020 - Analysis - IEA," 2021. [Online]. Available: https://www.iea.org/articles/global-energyreview-co2-emissions-in-2020. [Accessed: 05Jul-2021].

[16] S. Mahapatra and P. Chandra, "Clinically practiced and commercially viable nanobio engineered analytical methods for COVID-19 diagnosis," Biosens. Bioelectron., vol. 165, p. 112361, Oct. 2020.

[17] A. N. Konwar and V. Borse, "Current status of point-of-care diagnostic devices in the Indian healthcare system with an update on COVID-19 pandemic," Sensors Int., vol. 1, p. 100015, Jan. 2020.

[18] S. Sharma, S. Basu, N. P. Shetti, and T. M. Aminabhavi, "Current treatment protocol for COVID-19 in India," Sensors Int., vol. 1, p. 100013, Jan. 2020.

[19] "PRESS RELEASE How India ramped up COVID-19 testing capacity,” 2020. [Online]. Available:

https://www.icmr.gov.in/pdf/press_realease_file S/ICMR_Press_Release_India_testing_story_20 052020.pdf. [Accessed: 07-Jul-2021].

[20] "Covid-19 peak over; pandemic can be controlled by February 2021: Govt-appointed panel | India News - Times of India,” 2020. [Online]. Available: https://timesofindia.indiatimes.com/india/nofresh-lockdowns-recommended-at-local-levelgovernment-appointed-panel-on-covid19/articleshow/78732643.cms?from=mdr. [Accessed: 05-Jul-2021].

[21] The Lancet, "India's COVID-19 emergency," The Lancet, vol. 397, no. 10286. Elsevier B.V., p. 1683, 08-May-2021.

[22] A. Bhuyan, "Experts criticise India's complacency over COVID-19," Lancet (London, England), vol. 397, no. 10285, pp. 1611-1612, May 2021.

[23] "Kumbh Mela: how a superspreader festival 
seeded Covid across India | India | The Guardian," 2021. [Online]. Available: https://www.theguardian.com/world/2021/may/ 30/kumbh-mela-how-a-superspreader-festivalseeded-covid-across-india. [Accessed: 05-Jul2021].

[24] K. Thiagarajan, "Why is India having a covid-19 surge?," BMJ, vol. 373, p. n1124, Apr. 2021.

[25] "India Covid explainer: What we know about the B.1.617 variant," 2021. [Online]. Available: https://www.cnbc.com/2021/05/11/india-covidexplainer-what-we-know-about-thebpoint1point617-variant.html. [Accessed: 05Jul-2021].

[26] O. P. Choudhary, Priyanka, I. Singh, and A. J. Rodriguez-Morales, "Second wave of COVID19 in India: Dissection of the causes and lessons learnt," Travel Med. Infect. Dis., vol. 43, p. 102126, Sep. 2021.

[27] "Covid-19 in India: Why second coronavirus wave is devastating - BBC News," 2021. [Online]. Available: https://www.bbc.com/news/world-asia-india56811315. [Accessed: 06-Jul-2021].

[28] S. Kumar Kar, R. Ransing, S. M. Yasir Arafat, and V. Menon, "Second wave of COVID-19 pandemic in India: Barriers to effective governmental response," 2021.

[29] "Mortality 'significantly' increased in 2nd Covid wave in India: study | India News, The Indian Express," 2021. [Online]. Available: https://indianexpress.com/article/india/mortality -significantly-increased-in-2nd-covid-wave-inindia-study-7387919/. [Accessed: 06-Jul-2021].

[30] V. K. Jain, K. P. Iyengar, and R. Vaishya, "Differences between First wave and Second wave of COVID-19 in India," Diabetes Metab. Syndr. Clin. Res. Rev., vol. 15, no. 3, pp. 10471048, May 2021.

[31] S. Bagcchi, "The world's largest COVID-19 vaccination campaign," Lancet. Infect. Dis., vol. 21, no. 3, p. 323, Mar. 2021.

[32] "Why Covid vaccine producer India faces major shortage of doses." [Online]. Available: https://www.cnbc.com/2021/05/05/why-covidvaccine-producer-india-faces-major-shortageof-doses.html. [Accessed: 06-Jul-2021].

[33] "How India's vaccine drive went horribly wrong - BBC News," 2021. [Online]. Available: https://www.bbc.com/news/world-asia-india57007004. [Accessed: 06-Jul-2021].

[34] "Why did India export millions of Covid vaccines? - Quartz," 2021. [Online]. Available: https://qz.com/2001534/why-did-india-exportmillions-of-covid-vaccines/. [Accessed: 06-Jul2021].

[35] "Covid-19 in India: Cases, deaths and oxygen supply - BBC News," 2021. [Online]. Available: https://www.bbc.com/news/world-asia-india56891016. [Accessed: 07-Jul-2021].

[36] "As the pandemic rages, desperate Indians are turning to online crowd-sourcing for help little state resources, citizen-led online initiatives are helping people find everything from oxygen to ICU beds. - Rest of World," 2021. [Online].
Available:

https://restofworld.org/2021/pandemic-

desperate-indians-turning-online-

crowdsourcing-for-help/. [Accessed: 07-Jul2021].

[37] "Indians are forced to change rituals for their dead as COVID-19 rages through cities and villages," 04-May-2021. [Online]. Available: https://theconversation.com/indians-are-forcedto-change-rituals-for-their-dead-as-covid-19rages-through-cities-and-villages-160076.

[Accessed: 07-Jul-2021].

[38] "Indian doctors fighting coronavirus now face social stigma - Quartz India," 25-Mar-2020. [Online]. Available: https://qz.com/india/1824866/indian-doctorsfighting-coronavirus-now-face-social-stigma/. [Accessed: 07-Jul-2021].

[39] "The social impact of COVID-19 on India," 2020. [Online]. Available: https://www.thebridgechronicle.com/opinion/so cial-impact-covid-19-india-49313. [Accessed: 07-Jul-2021].

[40] "PM Modi's lockdown announcement prompts mass 'panic buying' across India | The News Minute," 25-Mar-2020. [Online]. Available: https://www.thenewsminute.com/article/pmmodi-s-lockdown-announcement-promptsmass-panic-buying-across-india- 121058. [Accessed: 07-Jul-2021].

[41] 'India's second Covid-19 wave: the impact of social determinants of health | IHP," 2021. [Online]. Available: https://www.internationalhealthpolicies.org/blog s/indias-second-covid-19-wave-the-impact-ofsocial-determinants-of-health/. [Accessed: 07Jul-2021].

[42] R. Mukhra, K. Krishan, and T. Kanchan, "COVID-19 Sets off Mass Migration in India," Arch. Med. Res., vol. 51, no. 7, pp. 736-738, Oct. 2020.

[43] "Across the country, migrants still forced to walk thousands of miles | Latest News India Hindustan Times," 09-May-2020. [Online]. Available:

https://www.hindustantimes.com/indianews/similar-scenes-in-several-states-despitenew-trains/story-

YL9qNcF315SA50645aj1DP.html. [Accessed: 08-Jul-2021].

[44] R. Choudhari, "COVID 19 pandemic: Mental health challenges of internal migrant workers of India," Asian J. Psychiatr., vol. 54, p. 102254, Dec. 2020.

[45] "See how rural India has been overrun by the pandemic's second wave," 2021. [Online]. Available:

https://www.nationalgeographic.com/science/art icle/see-how-rural-india-has-been-overrun-bythe-pandemics-second-wave. [Accessed: 07-Jul2021].

[46] "The digital divide in India: How access to technology and reliable information affects India's response to the pandemic | Association for Progressive Communications," 09-Jun-2021. 
[Online]. Available: https://www.apc.org/en/node/37367. [Accessed: 08-Jul-2021].

[47] "Household Social Consumption on Education in India Ministry of Statistics and Programme Implementation," 2018.

[48] "Coronavirus | Digital divide curbs vaccine access in rural Telangana - The Hindu," 07-May2021. [Online]. Available: https://www.thehindu.com/news/national/telang ana/digital-divide-curbs-vaccine-access-inrural-telangana/article34508753.ece. [Accessed: 08-Jul-2021].

[49] "India Internet A Closer Look Into the Future," 2020.

[50] "Covid-19: How online classes have widened the digital divide for under-privileged students | India News - Times of India," 05-Jul-2021. [Online]. Available: https://timesofindia.indiatimes.com/india/covid19-how-online-classes-have-widened-thedigital-divide-for-under-privilegedstudents/articleshow/84146917.cms. [Accessed: 08-Jul-2021].

[51] "Press Note On Provisional Estimates Of Annual National Income 2020-21 And Quarterly Estimates Of Gross Domestic Product For The Fourth Quarter (Q4) Of 2020-21 National Statistical Office Ministryof Statistics \& Programme Implementation Government Of India," 31-May-2021. [Online]. Available: http://mospi.nic.in/sites/default/files/press_relea se/Press Note_31-05-2021.pdf. [Accessed: 09Jul-2021].

[52] "Impact on Indian economy after the COVID-19 second wave - The Financial Express," 21-Jun2021. [Online]. Available: https://www.financialexpress.com/economy/imp act-on-indian-economy-after-the-covid-19second-wave/2275353/. [Accessed: 09-Jul2021].

[53] "The pandemic in data: How Covid-19 has devastated India's economy," 09-Jul-2021. [Online]. Available: https://scroll.in/article/999275/the-pandemic-indata-how-covid-19-has-devasted-indiaseconomy. [Accessed: 09-Jul-2021].

[54] "India's middle class shrinks amid COVID-19 as China sees less change | Pew Research Center," 18-Mar-2021. [Online]. Available: https://www.pewresearch.org/facttank/2021/03/18/in-the-pandemic-indiasmiddle-class-shrinks-and-poverty-spreadswhile-china-sees-smaller-changes/. [Accessed: 09-Jul-2021].

[55] R. A. Amit Basole, S. N. M. Radhicka Kapoor, and Rajendran Narayanan, "STATE OF WORKING INDIA 2021 Centre for Sustainable Employment," 2021.

[56] "Periodic Labour Force Survey (PLFS) (APRIL - JUNE 2020) Ministry of Statistics and Programme Implementation," 2020. 